\title{
Methotrexate encephalopathy presenting as choreoathetosis
}

\author{
Sanjeev Khera (1) , ${ }^{1}$ K P Shijith, ${ }^{2}$ Jyotindra Narayan Goswami (i) ${ }^{1}$
}

${ }^{1}$ Pediatrics, Army Hospital Research and Referral, New Delhi, India

${ }^{2}$ Radiodiagnosis, Army Hospital Research and Referral, New Delhi, India

\section{Correspondence to} Dr Sanjeev Khera;

kherakherakhera@gmail.com

Accepted 2 February 2021

\section{DESCRIPTION}

A 6-year-old boy with B-lineage acute lymphoblastic leukaemia was on intermediate risk Berlin-Frankfurt-Munster $2002 \quad$ (BFM-2002) chemotherapy protocol. He had favourable response to chemotherapy at the end of induction, as suggested by a negative minimal residual disease. During interim maintenance course of chemotherapy, high-dose methotrexate (HD-MTX) comprising MTX at $5 \mathrm{~g} / \mathrm{m}^{2}$ and intrathecal MTX at $12 \mathrm{mg}$ was administered. Seven days after the first cycle of HD-MTX, the patient was admitted with altered sensorium, irritability and generalised seizures. Central nervous system (CNS) examination did not show signs of meningeal irritation and there were no focal neurological deficits. Fundus evaluation showed grade 1 papilloedema. Contrastenhanced CT scan was normal. Cerebrospinal fluid (CSF) was normal and did not reveal blasts. The patient was managed with anticonvulsants and anti-raised intracranial pressure measures and he improved in the next 48 hours. He was continued on oral levetiracetam and was subjected to a second cycle of HD-MTX three weeks later.

Ten days after the second cycle of HD-MTX, the patient was admitted with choreoathetoid movements with preserved sensorium (video 1). No other abnormality was noted on CNS examination. Complete blood count and biochemical parameters were normal. CSF was normal and did not reveal blasts. He was managed with oral trihexyphenidyl and clonazepam. Abnormal movements were controlled within 6 hours. MRI of the brain performed after 4 days was suggestive of
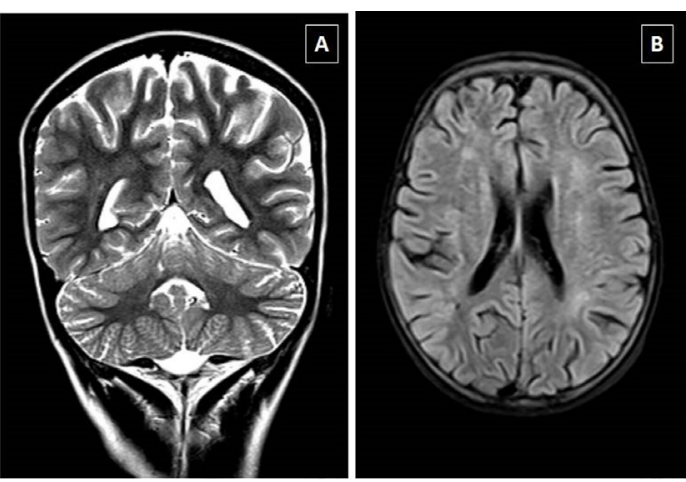

Figure 1 T2-weighted coronal (A)and axial fluidattenuated inversion recovery (B) images showing illdefined, irregular, scattered areas of periventricular and deep white matter hyperintensities involving the bilateral cerebral hemispheres, predominantly the peritrigonal regions and the bilateral frontal lobes.

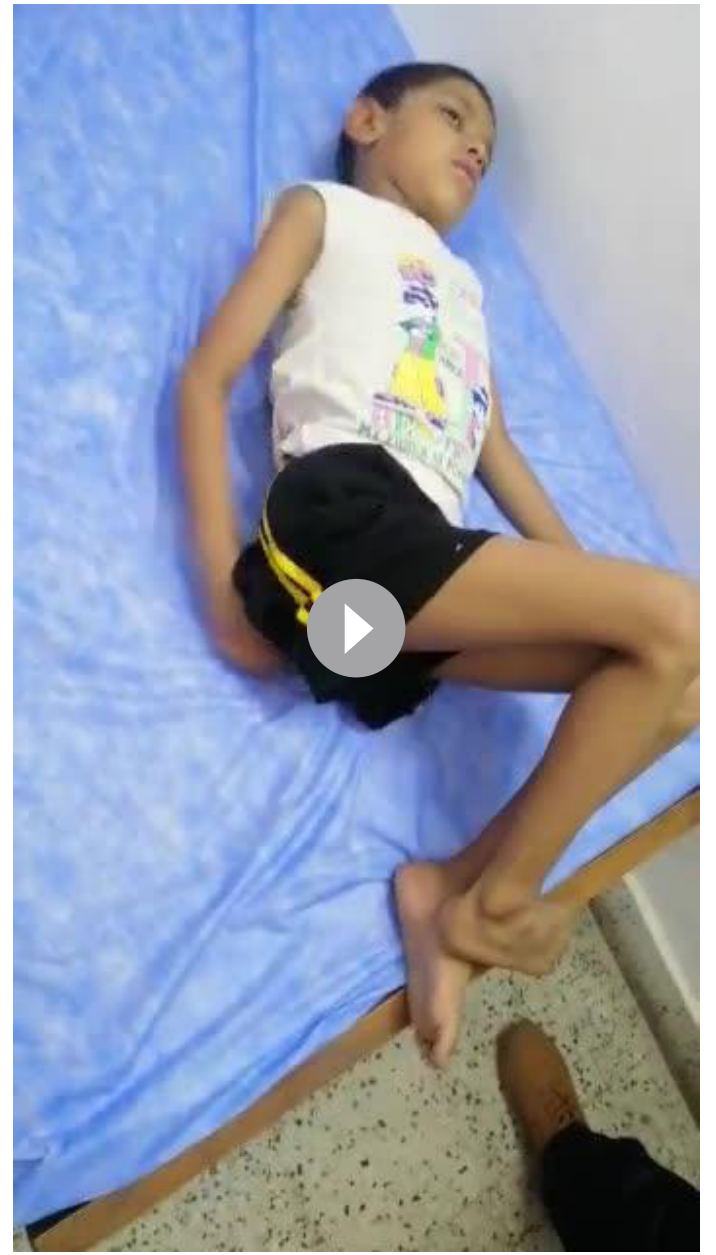

Video 1 Choreoathetoid movements with preserved sensorium in the index child.

MTX-induced leucoencephalopathy (figure 1A,B). Trihexyphenidyl and clonazepam were tapered and stopped, while levetiracetam was continued. Serum MTX levels at 36 hours after the start of MTX during cycles 1 and 2 were $1.82 \mu \mathrm{mol} / \mathrm{L}$ and 1.36 $\mu \mathrm{mol} / \mathrm{L}$ (normal value $<3 \mu \mathrm{mol} / \mathrm{L}$ ). He was rechallenged with two more cycles of HD-MTX and did not have any recurrence of symptoms suggestive of MTX-induced encephalopathy.

HD-MTX plays an important role in the curative therapy for haematological malignancies. It is associated with toxicities in $2 \%-12 \%$ of cases. ${ }^{1}$ MTX encephalopathy is seen in $0.8 \%$ of cases with haematological malignancies and presents within 2 weeks of exposure to MTX (intravenous and/ or intrathecal). MTX encephalopathy has varied clinical manifestations and radiological findings. The general clinical manifestations are headache, 
seizures, disorientation, confusion and focal neurological deficits. Extrapyramidal movements are extremely rare and are due to acute injury or disruption of the basal ganglia or its connections. Waxing-waning symptoms indicate progressive depolarisation of the axonal membranes rather than vascular occlusion. Re-exposure to MTX following episodes of resolved toxicity is generally safe. Classically, it presents with radiological changes in leucoencephalopathy (white matter hyperintensities on T2-weighted image and fluid-attenuated inversion recovery on MRI). ${ }^{23}$ Although choreoathetoid movements are primarily due to involvement of the striatum, indirect involvement of the cortical, subcortical and thalamic pathway leading to loss of inhibition may explain extrapyramidal manifestations. Frontal cortical pathway involvement was seen in the index child. We

\section{Learning points}

- Methotrexate (MTX) encephalopathy is a rare toxicity associated with high-dose MTX which has varied clinical and radiological manifestations and should be considered in a child with fresh-onset neurological symptoms and MTX exposure within 2 weeks.

- Choreoathetosis is an extremely rare manifestation of MTX encephalopathy. diagnosed MTX encephalopathy in the index child based on the temporal association with MTX exposure, recurrent symptoms with MTX exposure, self-limiting nature, characteristic MRI findings and after ruling out other causes.

Contributors SK conceptualised and wrote the manuscript and was involved in the diagnosis and management of the case. SKP and JNG were involved with diagnosis and management of the case.

Funding The authors have not declared a specific grant for this research from any funding agency in the public, commercial or not-for-profit sectors.

Competing interests None declared.

Patient consent for publication Parental/guardian consent obtained.

Provenance and peer review Not commissioned; externally peer reviewed.

\section{ORCID iDs}

Sanjeev Khera http://orcid.org/0000-0003-4754-8340

Jyotindra Narayan Goswami http://orcid.org/0000-0002-8537-7338

\section{REFERENCES}

1 Howard SC, McCormick J, Pui C-H, et al. Preventing and managing toxicities of highdose methotrexate. Oncologist 2016;21:1471-82.

2 Inaba $\mathrm{H}$, Khan $\mathrm{RB}$, Laningham $\mathrm{FH}$, et al. Clinical and radiological characteristics of methotrexate-induced acute encephalopathy in pediatric patients with cancer. Ann Oncol 2008:19:178-84.

3 Bhojwani D, Sabin ND, Pei D, et al. Methotrexate-Induced neurotoxicity and leukoencephalopathy in childhood acute lymphoblastic leukemia. J Clin Oncol 2014;32:949-59.

Copyright 2021 BMJ Publishing Group. All rights reserved. For permission to reuse any of this content visit

https://www.bmj.com/company/products-services/rights-and-licensing/permissions/

BMJ Case Report Fellows may re-use this article for personal use and teaching without any further permission.

Become a Fellow of BMJ Case Reports today and you can:

- Submit as many cases as you like

- Enjoy fast sympathetic peer review and rapid publication of accepted articles

- Access all the published articles

Re-use any of the published material for personal use and teaching without further permission

Customer Service

If you have any further queries about your subscription, please contact our customer services team on +44 (0) 2071111105 or via email at support@bmj.com.

Visit casereports.bmj.com for more articles like this and to become a Fellow 